\title{
Observations on the Role of the United Nations in Iraq in the Coming Year
}

\section{Christopher O’Sullivan*}

In April of 2004, the United Nations seemed poised to play an expanded role in the rebuilding of Iraq. The Bush Administration had dropped much of its opposition and began to embrace a UN-sponsored effort to internationalize the occupation and transfer sovereignty to the Iraqi people. Yet the ultimate role of the UN in Iraq remains in doubt. This is certainly due to a number of contemporary factors, many of them emanating from Washington. But it is also a consequence of Iraqi history, so much of which has been overlooked in the emotional atmosphere of the current crisis.

What roles can the United Nations play in Iraq? How likely is any role to be adopted? And what are the chances of success? As has been demonstrated in other recent United Nations interventions in Kosovo, Namibia, Cambodia, and East Timor, the UN could lend a semblance of legitimacy currently lacking in operations in Iraq. The UN could provide assistance to hold and monitor elections and oversee incremental steps toward state building. It could also provide support and assistance for refugee populations. For the most part, the UN has a stronger track record in these areas than does the United States acting alone. ${ }^{1}$ But controversies such as those that plagued the UN interventions in Bosnia and Somalia have cast a shadow on any hope that international forces under a UN umbrella will ameliorate the chaotic security situation in Iraq. Persistent violence in Iraq remains a major obstacle to an enhanced role for other states and the United Nations. And this obstacle may ultimately preclude a significant internationalization of the crisis.

Conceivably, the United Nations would need to work with the Iraqi personnel selected by the United States to govern Iraq, presenting its own set of problems. The UN would be challenged by the lack of legitimacy of the current Iraqi government. Future regimes, because of Washington's role in bringing them about, would continue to have difficulty establishing a sense of legitimacy. The government of Iyad Allawi still has little real autonomy. His regime is uncomfortably reminiscent of the various Britishsponsored regimes of Nuri Said (1888-1958), whose thirteen governments appeared to function primarily in the service of British imperial aims, discrediting him and the

* Christopher O'Sullivan is the author of Sumner Welles, Postwar Planning, and the Quest for a New World Order, 1937-1943 (New York: Columbia University Press, 2003), and is currently a Fulbright Visiting Professor of International Relations at the University of Jordan in Amman.

1 James Dobbins, ed., America's Role in Nation-Building: From Germany to Iraq (Santa Monica, CA: Rand Corporation, 2004). 
Hashemite rulers in the eyes of the Iraqi people. This history undoubtedly contributed to their assassination in the bloody Qassim coup of $1958 .^{2}$

Today there is a widespread assumption that Allawi's cabinet must clear many of its most important decisions with the U.S. Ambassador, John Negroponte. True or not, Iraq remains a de facto dominion of the United States, with little real sovereignty or independence of action. Most important, in the eyes of many Iraqis, the Arab news media, and much of the wider world, Negroponte is perceived as something akin to an imperial viceroy rather than an ambassador. This perception is reinforced by the size of Negroponte's mission, which resembles the imperial high commissions of old more than it does a modern embassy. It is hard to avoid the impression that important matters are still being determined by Washington. This is counterproductive, because the imperial legacy continues to cast long shadows over Iraq in particular and the region in general, exacerbating the potential to undermine any gains the international community might make in Iraq. The nation had been virtually run from the British Embassy in the past, and the size and activist tendencies of the current U.S. diplomatic contingent merely repeats an unhappy precedent. ${ }^{3}$

The United Nations has also had to contend with an unpredictable political context in the United States. The Bush Administration's approach to Iraq has been startlingly inconsistent, and the United Nations has had to react quickly to these abrupt shifts. There have been a number of stunning turns in the U.S. attitude toward the UN's role in Iraq in the past few months. At the end of April 2004, a faction within the Bush Administration, led by the president himself, signaled a desire to have the United Nations play a larger role in Iraq. ${ }^{4}$ April was indeed a cruel month in Iraq, with Iraqi and U.S. casualties mounting, along with the revelations from the Abu Ghraib prison scandal. While President Bush, with his reelection campaign looming, has made several statements favorable to an expanded UN role, key members of the administration, particularly Secretary of Defense Rumsfeld and Vice President Cheney, have been cool to the notion of internationalizing the Iraqi occupation. Administration officials, too, cite

2 The perception that Nuri was a pawn of British imperialism brought nationalist agitation in Iraq to a boil on many occasions, eventually leading to the overthrow of the Hashemite dynasty in 1958. FO (Foreign Office) 371/128041, Michael Wright, Confidential Foreign Office memorandum, "The Achievements of Nuri Said," 9 July 1957, British National Archives (BNA), Kew.

3 The British archives are replete with evidence that the British Embassy in Baghdad virtually ran Iraq after the termination of the League of Nations mandate, and continued to meddle in Iraq's affairs up until the 1958 revolution. See, for example, FO 371/27061, Winston Churchill to Sir K. Cornwallis (Baghdad), 11 March 1941, BNA, Kew; FO 371/27100, Sir Basil Newton (Baghdad) to Sir Anthony Eden, 17 January 1941, BNA, Kew. See also Douglas Little, American Orientalism: The United States and the Middle East Since 1945 (Chapel Hill: University of North Carolina Press, 2002), 198-206.

4 The use of the word "faction" is appropriate. It is not clear that the administration has achieved a consensus on what it ultimately intends to do with Iraq and what role the UN will play there. See James Mann, Rise of the Vulcans: The History of Bush's War Cabinet (New York: Viking, 2004), 365-72. 
the chaotic security situation as an impediment to obtaining enhanced UN or allied assistance in Iraq. But it is not at all clear that key members of the administration are eager to cede authority, even if the security situation were to improve. To many of the neoconservatives, the taking of Iraq was the culmination of years of effort. ${ }^{5}$ They are not eager to turn Iraq over to the United Nations merely to aid the president's reelection prospects. An entrenched opposition to even a limited role for the UN may perpetuate the infighting within the Bush Administration into a second term. ${ }^{6}$

The decision in April 2004 to have the president embrace the mission of UN special envoy Lakhdar Brahimi, and the administration's simultaneous moves against its former ally, Ahmad Chalabi of the Iraqi National Congress (INC), marked a startling U-turn in the U.S. approach to Iraq. These shifts signaled a complete reversal of the course the administration had followed for the previous year. Chalabi had been one of the Bush Administration's chief sources of information about Iraq prior to the invasion. His connections with the administration were said to be both broad and deep. Yet today, the Bush Administration appears to be backing his probable trials in both Iraq and neighboring Jordan. ${ }^{7}$

\section{The United Nations, Iraq, and the U.S. Elections}

The administration remains divided over Iraq policy and the ultimate role of the UN, and it is not clear that it is committed to a UN engagement in Iraq for the long term. What might happen in a second Bush Administration is anyone's guess. Little has been said about its long-term vision for a UN role in Iraq beyond vague generalities about guaranteeing human rights and democracy. Little has been said about the disposition of Iraqi oil revenues. Instead, much effort is being directed at making Iraq into an adjunct of American power in the region through long-term base agreements. This is hardly a recipe for increasing the legitimacy of the new regime.

The question has also been raised, with the 2004 presidential campaign now in full swing, about what John Kerry's election might portend for a larger UN role in Iraq. A Kerry Administration would have a freer hand, unencumbered by the bitterness of the past two years, to reestablish links to allies and the UN and to make fresh overtures to

5 See, for example, Nile Gardiner and James Phillips, "A Limited Role for the United Nations in Postwar Iraq," The Heritage Foundation, 22 January 2004; available at http://www.heritage.org/Research/MiddleEast/wm402.cfm.

6 Furthermore, leaks to the American press from anonymous senior administration officials have undermined the president's efforts since April to have the United Nations play a larger role in Iraq. Although Bush has signaled a change of course over Iraq, his administration does not seem to be speaking with one voice.

7 Chalabi even sat with First Lady Laura Bush during the president's State of the Union Address, and one of the rationales put forward by the conservative think tanks for the invasion was to place the INC in power in Baghdad. Many in Washington seemed to believe that the INC's legitimacy could be manufactured on the Potomac and transplanted to the banks of the Euphrates. Events on the ground in Iraq between April 2003 and April 2004 proved otherwise and provoked this startling reassessment. 
states in the Middle East. But Kerry would also inherit the debilitating security problems of Iraq, which show no signs of abating. It is this daunting security crisis that prevents a larger role for the UN. A major stumbling block to an enhanced UN role in Iraq is the ongoing Iraqi resistance to the occupation forces and the inability of coalition forces to provide security.

Three weeks after the invasion of Iraq, the U.S. administration declared that the mission in Iraq was accomplished. Even then it was not clear what the ultimate disposition of Iraq would be. Flush with apparent victory, Washington initially sought to limit the UN's role in Iraq and pressed ahead with its own plans to pacify the region and its restive populations through the efforts of Jay Garner, and later L. Paul Bremer and the Coalition Provisional Authority (CPA). But, in the face of continuing resistance and civil chaos throughout Iraq (reminiscent of the resistance to British imperial power during and after the mandate), and plagued by mounting U.S. casualties, the administration appealed for a more proactive role for the UN. Any effort to have the $\mathrm{UN}$ bear more of the burden in Iraq continues to be seriously undermined by consequences of the August 2003 car bomb that destroyed UN headquarters in Iraq, a further demonstration of the chaotic security situation. Included among the many dead was Sergio Vieira de Mello, the UN's head of mission.

A Kerry victory might bring more enthusiasm to securing UN and allied cooperation in Iraq. But many of the underlying problems of Iraq, themselves the consequences of the war, plus the failure to plan for the postwar period and, more broadly, Iraqi history and the legacy of foreign domination, will continue to plague whoever is in the White House in 2005. Furthermore, there is no guarantee that the United Nations, even if it were to be committed to Iraq in a more comprehensive way, would have any more success than the U.S.-dominated occupation has. Because of the ongoing violence, other nations will continue to be reluctant to commit forces in any meaningful way. Whatever the scenario after 20 January 2005, U.S. forces are likely to be in Iraq for the long haul, and no amount of enhanced UN, NATO, or allied cooperation is going to change that. Few observers, other than Morton Abramowitz, the former president of the Carnegie Endowment for International Peace, have challenged the notion that the stakes in Iraq are sufficiently large to justify the sacrifice America seems likely to make. ${ }^{8}$

There is no agreement as to what inspires the determined Iraqi resistance. In the face of persistent violence, there have been calls in Washington for stronger measures. For example, a recent article by the neoconservative historian Niall Ferguson titled "Recovering Our Nerve" in the Nixon Center's foreign policy journal, The National Interest, argues that the United States merely needs to stiffen its upper lip and act more

8 Morton Abramowitz, “Does Iraq Matter?” The National Interest 75 (Spring 2004). 
unilaterally in Iraq and not shy away from using its military power. ${ }^{9}$ But the current phase of the Iraq war is essentially a war of legitimacy. In essence, the U.S. occupation - and thus anyone associated with the occupation-lacks legitimacy. The Iraqi resistance now emanates from multiple sources, and may be growing and strengthening with each passing month. Elements of the ancien regime are now joined by Islamic militants and an increasingly determined Shiite militia movement. One factor that unites these disparate factions (other than their shared opposition to the U.S. presence in Iraq) is the widespread notion that the interim government lacks legitimacy. It lacks legitimacy because it was put in place by U.S. military power and remains in place at the pleasure of that power. The United Nations can certainly help lend the effort in Iraq some semblance of legitimacy, but there may be only so much the UN can do at this point. Events of the past two years cannot now be undone, and the international community is going to have to live (perhaps for years to come) with the consequences of how the war in Iraq was launched and subsequently prosecuted. But the UN will also have to contend with the consequences of Iraqi history, and it is this historical context in Iraq that has gone largely overlooked.

\section{Iraq's History: A Crucial Piece of the Contemporary Puzzle}

That so many in the Bush Administration assumed that the postwar occupation of Iraq would go relatively smoothly demonstrates an appalling ignorance of the Iraqi people and their history. Iraq's history reveals some of the reasons why the U.S. occupation has not gone smoothly. Despite the increased attention Iraq has received in the West since its 1990 invasion of Kuwait, this history, particularly how it has conditioned and shaped current events, remains relatively unknown - this despite the emergence of much insightful scholarship in the last decade. ${ }^{10}$ Throughout its short history as a state, Iraq has been acutely sensitive to outside interference of any sort. In this era of heightened national consciousness and self-determination, occupations anywhere, without the essential support of international legitimacy, have rarely gone well. "Occupations usually generate mobilized opposition," international affairs specialist Robert Keohane has

9 “. . it was madness," Ferguson writes, "to execute a volte face and call in the United Nations in the belief that it might help legitimize the handover of sovereignty. All that UN envoy Lakhdar Brahimi has done so far has been to undermine the credibility of the quite adequate system established by CPA administrator L. Paul Bremer. What was wrong with the Iraqi Governing Council? What was wrong with the basic law upon which it (miraculously) managed to agree? The arrival of Brahimi on the scene has threatened to nullify Bremer's achievements." Niall Ferguson, "Recovering Our Nerve," The National Interest 76 (Summer 2004). Ferguson's comments demonstrate what might be called the neo-imperial mindset. It is pervasive throughout the administration, and in the conservative think-tank culture. But such notions reveal a fundamental misunderstanding of what really ails Iraq. There is not much thought given to what might motivate the resistance. Furthermore, such neo-imperial prescriptions have been rendered irrelevant by the facts on the ground.

10 See, for example, Toby Dodge, Inventing Iraq: The Failure of Nation Building and a History Denied (New York: Columbia University Press, 2003). 
noted. "It does not matter who the occupier is. The U.S. in Vietnam, the Soviet Union in Afghanistan, Israel in the West Bank and Russia in Chechnya have had the same experience. Whatever the motivation, and despite overwhelming military power, people resist occupying forces." "11 Yet romantic notions about the imperial legacy in Iraq and the broader Middle East region persist, perhaps owing to ignorance of the consequences of European imperialism for Iraq and its peoples. Iraq's destiny has already been irreparably altered by international involvement in the region. ${ }^{12}$

The United Nations should beware of embarking upon an expanded role in Iraq where it does not have some say in the nation-building process. The U.S. will inevitably have interests different from those of the international community, particularly over the disposition of Iraqi oil revenues and the ultimate status of U.S. forces and bases in Iraq. For the UN, the lamentable example of the League of Nations mandate for Iraq offers a cautionary tale. In the wake of World War I, the British ultimately had to consent to a League of Nations mandate for the area, with themselves as the mandatory power for what would subsequently become Iraq. This did nothing to assuage the sting of the betrayal perpetrated by the British, and Iraq's instability was intensified by the widespread social and demographic engineering that the British pursued under the mandate. ${ }^{13}$ Then as now, the peoples who inhabited Iraq were never passive bystanders. With false British promises of independence still fresh in their minds, they committed numerous acts of resistance against British imperial power, which had alienated the growing urban, educated, middle class and poisoned the political climate.

The complexities of Iraq's demographic, ethnic, and religious composition also have the potential to provoke discord between the U.S. and the UN. To understand them today is to understand whence they came. Again, British imperial machinations created patterns in Iraq that promise to challenge whomever seeks to create future state institutions. While the Sunni minority was promoted by the British, the demographic

11 Robert O. Keohane, "Americans Must Prepare for the New Crisis by Taking on Board Seven Lessons of the Iraq War," The Financial Times, 8 July 2004.

12 Iraq shares much with other Middle East trouble spots that have concerned the United Nations, such as Palestine and Lebanon. Like those areas, many of Iraq's contemporary problems are largely attributable to its experience under the League of Nations mandate. During the First World War, declarations by the British raised expectations that local Arab factions would achieve self-government in the area. Upon such promises - such as the McMahon-Hussein notes of 1915-16 - many regional Arab factions fought with the British Empire against Ottoman forces in the region. Britain had other designs for the region, however, and desired to rule Mesopotamia directly. The British betrayed their promises to the Arabs, seeking instead an Anglo-French partition of the Middle East and a division of spoils under the 1916 Sykes-Picot Agreement. Revelation of this secret agreement caused consternation among the Arabs as well as long-term bitterness.

13 Iraq's arbitrary borders in no way reflect underlying cultural patterns or historical relationships. The artificial creation of this nascent state was reinforced by the British imperial effort to manufacture a ruling elite from the minority Sunni population, installing as king the formerly Arabian-based Hashemite princeling Faisal ibn Hussein al Hashem in 1921, following a plebiscite of dubious credibility. 
composition of the new state remained largely Shiite, with a substantial Kurdish minority. Both of these peoples were often marginalized by the British-imposed governing elite. The British Empire sought to protect its interests without regard for local aspirations, making the situation much worse than it otherwise might have been. The British role in Iraq was traditionally imperial, backing friendly elites and factions to promote British imperial aims in the region and favoring the Sunni minority. London also secured long-term contracts, on highly favorable terms, for extracting Iraq's oil. Recent headlines about the large sums from Iraqi oil that have been extracted by U.S. contractors, particularly the well-connected Halliburton and its subsidiary Kellogg Brown \& Root, will further undermine efforts to demonstrate that the interim government is legitimate and promotes the interests of the Iraqi people. ${ }^{14}$ With recent revelations about the Oil for Food scandal at the UN, the United Nations cannot do much at this point to lend credibility to the disposition of Iraqi oil and the revenues generated from it either. But long as the United States continues to determine the ultimate use of the oil revenues, the Iraqi people will be left with the impression that this is a return to the days of oil deals favoring the imperial power at the expense of the Iraqi nation. ${ }^{15}$

\section{The United Nations and Efforts to Create Legitimate Institutions of Self- Government in Iraq}

There are useful parallels between the U.S. effort to have the United Nations legitimize its actions in Iraq and the British domination of Iraq under the cover of a League of Nations mandate between 1922 and 1932. The mandate over Iraq formally ended in 1932, but the British continued to see Iraq as part of their informal empire. ${ }^{16}$ They maintained bases to support their frequent interventions into Iraqi political life and to secure their long-term economic interests. ${ }^{17}$ Historian of Iraq Charles Tripp sees the British mandate as "a troubling legacy which the grant of formal independence did little to remove." ${ }^{18}$ Despite the termination of the mandate, many Iraqis continued to resist British imperial domination of Iraqi life and politics. Post-mandate Iraqi history was marked by numerous uprisings and acts of resistance against British imperial

14 See, for example, Ariana Eunjung Cha, "\$1.9 Billion of Iraq's Money Goes to U.S. Contractors," The Washington Post, August 4, 2004. Cha's article notes that Kellogg Brown \& Root was paid $\$ 1.66$ billion from Iraqi oil revenues, which was tacked on to a no-bid contract and is now subject to several investigations.

15 The British also sought to secure Iraq as a strategic outpost in the region, maintaining British bases with substantial forces, and terrorizing the civilian population with aerial bombardment at the earliest sign of resistance. The United Nations might want to discern what Washington's long-term intentions are for Iraq. The United Nations and its member nations might want to avoid getting themselves into a position where they are defending U.S. bases in Iraq. CO (Colonial Office) 730/159/16, "The Future of Iraq," 1930-31, British National Archives, Kew.

17 CO 730/168/7, "Use of Aerodromes in Iraq by Britain," 1931, British National Archives, Kew.

18 Charles Tripp, A History of Iraq (Cambridge: Cambridge University Press, 2000), 75. 
power and its Hashemite allies - particularly the 1941 Rashid Ali rising, which nearly toppled the much-loathed British military presence during World War II, and the 1948 Al-Wathba rising, which was sparked by the unpopular Portsmouth Treaty with Britain. The culmination of this persistent resistance was the 1958 coup that overthrew the pro-Western ruling elite. This history has made Iraq unusually sensitive to outside interference or exploitation of any kind.

Previous UN efforts at state-building in other parts of the world are less than reassuring. The worst-case scenario cited thus far has been Somalia, where the United States gradually altered the UN mission from one of humanitarian relief to one of nation-building and warlord eradication. The Somalia mission ended in disaster as the death of more than a score of U.S. peacekeepers created a firestorm of controversy, leading to a withdrawal of U.S., and later, UN forces. The Somalia debacle also undermined confidence in United Nations efforts at peacekeeping, peace-enforcement, and nation-building. Many analysts believe a more positive model might be Kosovo. But even in Kosovo there are doubts that the United Nations has had much success in resolving the underlying problems, and there are concerns that the eventual departure of the international community will provoke a rekindling of the ethnic conflict. Most important, while previous examples of UN intervention may provide some insight into what might or might not happen in Iraq, the Iraqi case presents unique perils and difficulties that were not factors in those other interventions. The United Nations will have to grapple with the Sunni-Shia-Kurd dilemma, and the UN's record of dealing with intrastate conflicts is hardly stellar. ${ }^{19}$

The success or failure of the United Nations in Iraq may also have consequences for other areas of UN involvement in the Middle East. The UN is no stranger to the region and its many crises. It has played a substantial role in numerous controversies in the Middle East, including the questions of Palestine and the Arab-Israeli dispute. The UN played a key role in determining the partition plan of 1947 that led to the creation of the state of Israel, and has dispatched small peacekeeping and observer missions to the Sinai Peninsula, Gaza, Lebanon, and the Golan Heights. It figured prominently in addressing the refugee crisis that occurred in the aftermath of the first Arab-Israeli war, and it continues humanitarian relief efforts in the occupied territories. The UN also passed a series of Security Council resolutions that serve as a loose framework in the search for a settlement between Israel and the neighboring Arab states and, later, Israel and the Palestinians. But the Israeli-Palestinian dispute-an explosive issue with

19 Some observers, such as Peter Galbraith, have endorsed the notion that whoever has responsibility for state-building in Iraq should pursue what he labels the "Yugoslav model" that would give each of Iraq's peoples their own republic. Peter W. Galbraith, "How to Get Out of Iraq," New York Review of Books, 13 May 2004. See also, Leslie Gelb, "The ThreeState Solution," op-ed in the New York Times, 25 November 2003. 
broader regional and international implications - continues unabated. ${ }^{20}$ Successive Israeli governments remain committed to excluding the UN from the search for a resolution to the conflict, and it remains doubtful that even moderate success in Iraq would lead the United Nations to play a greater role in the Israeli-Palestinian conflict anytime soon.

\section{Conclusion}

The de jure transfer of sovereignty from the CPA to the interim Iraqi government has now occurred, but little has been done to secure a long-term United Nations role in the rebuilding of Iraq. The most important function the United Nations can now play in Iraq is in easing the way for other nations to contribute to the rebuilding process, and seeking to establish some semblance of legitimacy for an international stabilization effort to create institutions of self-government. There is a need for external assistance on many fronts, but it is not clear that the Bush Administration comprehends this vital role the UN could play before there can be any improvement of the situation on the ground in Iraq.

The UN might be able to ease into some of the roles that U.S. forces are now fulfilling. Whether this would enhance the legitimacy of operations in Iraq is speculative. At this point, in light of the events of the last year and a half, any outside presence is likely to be met with resentment and resistance. The UN can enhance legitimacy; it may also be perceived as merely window dressing for the latest imperial project. A greater role for the United Nations might mark an improvement. But at this point in the war, and in light of what has already occurred, the chances that the UN can establish legitimacy in Iraq are growing about as dubious as the U.S. attempt to manufacture legitimacy during the past eighteen months. Notions persist that what is needed for success in Iraq is a heavier dose of military force and violence. A crisis of legitimacy, such as has been occurring in Iraq since April 2003, is essentially a political problem, to be resolved by political means. Further attempts to resolve Iraq's problems militarily are, ultimately, futile, and even counterproductive.

20 The controversy over Palestine shares numerous commonalities with other crises the UN has been involved with in the Middle East, such as Iraq and Lebanon. All are partial consequences of imperial contact and colonial social engineering. The flawed League of Nations mandates in Palestine, Lebanon, and Iraq had a profound impact on their later evolution, as did the problematic application of the concept of the nation-state, creating artificial boundaries with no historical, ethnic, or religious basis. Most of the countries in the region are not the natural and historical products of time and space, but rather configurations arrived at arbitrarily by external powers. Moreover, ongoing Western interest in the region's resources - particularly oil — has had a profound impact on political developments. 
THE QUARTERLY JOURNAL

\section{Bibliography}

Abramowitz, Morton. "Does Iraq Matter?" The National Interest 75 (2004).

Dobbins, James. America's Role in Nation-Building: From Germany to Iraq. Santa Monica, CA: Rand Corporation, 2004.

Dodge, Toby. Inventing Iraq: The Failure of Nation Building and a History Denied. New York: Columbia University Press, 2003.

Galbraith, Peter W.. "How to Get Out of Iraq." New York Review of Books (2004).

Keohane, Robert O.. "Americans Must Prepare for the New Crisis by Taking on Board Seven Lessons of the Iraq War." The Financial Times (2004).

Little, Douglas. American Orientalism: The United States and the Middle East Since 1945 . Chapel Hill: University of North Carolina Press, 2002.

Mann, James. Rise of the Vulcans: The History of Bush's War Cabinet. New York: Viking, 2004.

O'Sullivan, Christopher. Sumner Welles, Postwar Planning, and the Quest for a New World Order, 1937-1943 . New York: Columbia University Press, 2003.

Tripp, Charles. A History of Iraq. Cambridge: Cambridge University Press, 2000. 